\title{
Risk, Race and Incumbents: The Effect of Authoritarianism on the Vote for Incumbents in 2012
}

\author{
Maryann Kwakwa \\ University of Notre Dame, South Bend, USA
}

\begin{abstract}
Using data from the 2012 American National Election Studies (ANES), I assess the impact of authoritarianism on the likelihood to vote for Senate, House and presidential incumbents amongst White and Black Americans. I find that the influence of authoritarianism on the vote for incumbents depends on the race of the voter and the party identification of the incumbent. This suggests that risk-averse voting behavior amongst authoritarians is a function of party affiliation in addition to perceived threat, and heavily qualified by race.
\end{abstract}

Keywords: authoritarianism, race, risk-attitudes, vote choice

\section{Introduction}

Assuming that authoritarians tend to be risk averse, are they more likely to vote for incumbents as opposed to challengers? Authoritarianism is of particular interest to political scientists as an explanation for voting behavior because it increases polarization in latent but consequential ways. Authoritarianism is closely related to conservatism, which is widely accepted as the lynchpin of the Republican ideology. As a result, the effect of authoritarianism amongst White constituents is broadly studied, and research on the subject is readily available. Conversely, the literature on authoritarianism does not typically focus on the ways in which it affects the political decision-making of racial minorities. In this article, I ask whether we can make generalizations about the voting behavior of authoritarians regardless of race and find that, when it comes to the vote for incumbents, race is a significant factor. Using data from the 2012 American National Election Studies (ANES), I assess the impact of authoritarianism on the likelihood to vote for congressional and presidential incumbents. My findings suggest that the effect of authoritarianism on the vote for incumbents differs according to race and the party identification of the incumbent. Although it is a simple and somewhat intuitive conclusion, the results reveal that there is a tension between some key characteristics of authoritarianism and underscore the importance of wider discussions about its effects on the voting behavior of Black constituents in particular.

\section{Authoritarianism and Risk}

Feldman (2003) and Stenner (2005) conceive of authoritarianism as a tendency that is grounded in a need for order and a desire to protect the social status quo. Authoritarianism and ethnocentrism are often conflated because the effects of the two are similar. Unlike ethnocentrism, which is fueled by in-group loyalty and out-group bias, a preference for time-honored, social norms is what distinguishes those who score high on authoritarianism from those who do not (Stenner, 2005). Given the racial foundations of American society, the 
characteristics that define what it means to be "American" are often derived from a social hierarchy that privileges Whites (Masuoka \& Junn, 2013). The time-honored norms that authoritarians value so deeply are heavily predicated on racial categorizations and, indeed, scholars have shown a strong relationship between authoritarianism and negative affect toward Black and Arab Americans (Sniderman \& Piazza, 1993; Huddy et al., 2005). Such findings bolster the common but faulty assumption that authoritarianism is a variant of ethnocentrism, and limits the scope of analysis to White Americans who tend to exhibit ethnocentric tendencies quite strongly in their voting behavior (Kam \& Kinder, 2012). Furthermore, because authoritarians have a greater than average need for order and a tendency to be social conformists, authoritarianism is also mistakenly characterized as conservatism. Perhaps the fact that Republican identifiers are growing more authoritarian while their Democratic counterparts are not lends support to the notion that authoritarianism and conservatism are one and the same, but further research on both subjects clearly indicates that they are not (Hetherington \& Weiler, 2009). What distinguishes authoritarianism from other dispositions like it is its unique relationship to situationism.

Situationism is the idea that the impact of authoritarianism "... manifests itself in politically relevant ways only under threatening circumstances" (Hetherington \& Weiler, 2009). The propensities that characterize authoritarianism are, therefore, highly contingent on context. Authoritarianism is impactful because it is a worldview; it shapes how people interpret events and how they behave as a result of those interpretations. When assessing the influence of authoritarianism, whether or not a given situation presents a sufficiently credible threat is of little importance. What matters most is whether or not those scoring high on authoritarianism perceive the situation as threatening. For authoritarians, the mere perception of threat incites a need to solidify social norms and they elect to do this by relying on established authorities to reinforce order (Hetherington \& Weiler, 2009). Moving forward, it is important to emphasize that situationism has no partisan caveats. Authoritarians are most likely to support the authority figures that they perceive to be the most capable of providing strong direction in a threatening situation. Order, not conservatism, drives the vote when it comes to authoritarianism and, therefore, in theory, threat can be leveraged to the advantage of either Democrats or Republicans depending on the nature of the solutions proposed in response to a threat.

In light of what is known about authoritarian tendencies, I make an additional claim: That those scoring high on authoritarianism will also tend to be risk-averse. A central assumption of this paper is that the need for order and clarity can be manifested as risk-averse voting behavior. Most theoretical models assume that voters are risk averse (Bartels, 1986; Alvarez, 1997) but Kam and Simas (2010) show that there is a spectrum of risk orientations that result in significantly different attitudes and behaviors. In comparison to risk-accepting citizens, risk-averse constituents are more drawn to candidates who offer certainty and stability; they also prefer those with more experience to those with less (Kam \& Simas, 2012). Because of their propensity to rely on established authorities, I argue that it would be more likely for authoritarians to exhibit predispositions akin to those of risk-averse citizens as opposed to risk-accepting ones when it comes to electoral choice.

Kam and Simas (2012) show that, in the 2008 and 2009 U.S. House elections, the most risk-adverse citizen was very unlikely to vote for a challenger (with a predicted probability of 0.09 ) whereas the most risk-accepting citizen was about eight times as likely to vote for the challenger (with a predicted probability of 0.75) (Kam \& Simas, 2012, p. 749). Their results add weight to my assertion about risk-aversion in relation to authoritarianism because, when it comes to choosing between incumbents and challengers, risk-averse citizens tend to elect incumbents, or, in the language of authoritarian literature, established authorities. If my intuition 
about the risk orientation of authoritarians is correct, they should, on average, be more likely to vote for incumbents than challengers. Overall, I demonstrate that the former statement must be qualified by race and party distinctions.

Stemming from my former assumption are two hypotheses, both of which I test using the 2012 ANES. The first is that those scoring high on authoritarianism will be more likely to vote for Senate, House and presidential incumbents. The second relates more specifically to the context of the 2012 elections. As aforementioned, situationism is an important aspect of authoritarianism. The 2012 ANES is the ideal dataset to test my hypothesis about the effect of authoritarianism on the vote for incumbents because the presidential incumbent, Barack Obama, presents an interesting theoretical puzzle for predicting authoritarian behavior.

Throughout his political career, the Republican Party has taken pains to characterize Obama as a social and political threat, fueling anti-Black and anti-Muslim sentiments to garner support amongst conservative constituents. Although Obama was the "established authority" in 2012, it seems as though, amongst some authoritarians, he was most likely viewed as a threat. The extant literature suggests that authoritarians have both a propensity to rely on established authorities and heightened political reactions to perceived threats, but it is not evident if one takes precedence over the other or when (Hetherington \& Weiler, 2009). Before President Obama, the typical presidential incumbent was a white, Christian male. Therefore, I argue that White authoritarians most likely viewed Obama as a threat whereas, because of Obama's membership to the African American community, it is very unlikely that Black authoritarians viewed him as such. Consequently, my second hypothesis is that, in 2012, White authoritarians would be less likely to vote for Obama whereas Black authoritarians would be more likely to vote for him. In short, I test whether there is a baseline tendency for authoritarians to vote for incumbents in the Senate and House and then seek to establish whether White authoritarians deviated from that tendency in the 2012 presidential election while Black authoritarians adhered to it.

\section{Data and Measures}

My independent variables are authoritarianism and race. For my measure of authoritarianism, I use an additive index of responses to a four-question battery on parenting orientations created and validated by the ANES. Specifically, the survey asks respondents to choose whether they thought it was more important for children to have (1) independence or respect or elders; (2) curiosity or good manners; (3) obedience or self-reliance; and (4) consideration or good behavior. To date, an additive scale of the former questions is the standard measure of authoritarianism in the field of political science. I coded responses as: 1 for non-authoritarian respondents, 1 for authoritarian respondents, and 0 for respondents who indicated that they valued "both" of the child-rearing values at either extreme of the spectrum. The race variable is coded as 0 for White respondents and 1 for Black respondents. I have three dependent variables: Senate, House and Presidential Incumbent Vote. The Senate and House Incumbent Vote variables are coded as the respondents' vote choice based on the party that the respondents voted for and the party identification (PID) of the incumbent in their state and/or district. I first determined which Senate and House incumbents ran for re-election in $2012^{1}$ and then sorted them by their PID (Republican or Democrat). For the Senate Incumbent Vote variable, Republican and Democratic incumbents were sorted by state; for the House Incumbent Vote

\footnotetext{
1 Retrieved from http://www.ballotpedia.org
} 
variable, they were sorted by state and district. Therefore, to clarify, if respondent $\mathrm{R}$ voted for a Republican from her state in the Senate election and the incumbent running for reelection from her state was, indeed, a Republican, then she was coded as having voted for an incumbent. However, if respondent $\mathrm{R}$ voted for the Democratic candidate from her state, then she was coded as having voted for a challenger. The same coding is used to determine whether respondents voted for Democratic incumbents running for reelection as well. The Presidential Incumbent Vote variable is simply a measure of whether respondents did or did not vote for President Obama.

In order to ensure that I truly capture the choice between voting for an incumbent or their opposition, I do not include open seat races in the Senate and House Vote variables. Open seat races could verify a variety of risk-averse characteristics amongst authoritarians specifically because they provide an opportunity to test candidate preference in relation to individual perceptions. However, to reiterate, one of my aims is to determine whether there is a baseline tendency for authoritarians to vote for incumbents. The inclusion of open seat races could make it slightly more difficult to observe this tendency if it exists. I also control for income, gender, age, education, and PID since they should all be theoretically related to vote choice.

Table 1

The Effect of Authoritarianism on Senate and House Incumbents, 2012 (Standard Errors in Parentheses)

\begin{tabular}{lcc}
\hline Dependent Variables & $(N=2,070)$ & $(N=2,850)$ \\
\hline Authoritarianism & Senate Incumbent Vote & House Incumbent Vote \\
Authoritarian (R) & $0.12 *$ & $0.10 * * *$ \\
& $(0.061)$ & $(0.023)$ \\
Authoritarian (D) & -0.04 & 0.01 \\
& $(0.011)$ & $(0.025)$ \\
Income & 0.002 & -0.003 \\
Female & $(0.008)$ & $(0.005)$ \\
& 0.07 & 0.14 \\
Age & $(0.113)$ & $(0.082)$ \\
& -0.003 & -0.003 \\
Education & $(0.003)$ & $(0.002)$ \\
& 0.08 & -0.05 \\
PID & $(0.055)$ & $(0.005)$ \\
Race: White & $-0.64 * * *$ & $-0.08 * * *$ \\
& $(0.031)$ & $(0.021)$ \\
Race: Black & -0.02 & 0.043 \\
& $(0.155)$ & $(0.114)$ \\
Source: 2012 Ameris & -0.01 & 0.15 \\
& $(0.225)$ & $(0.140)$ \\
\hline
\end{tabular}

Source: 2012 American National Election Studies; $* p<0.10 ; * * p<0.05 ; * * * p<0.01$.

Notes. Authoritarian (R) indicates the effect of authoritarianism when the incumbent is a Republican and Authoritarian; (D) indicates the effect of authoritarianism when the incumbent is a Democrat. Estimates do not include sample weights.

\section{Authoritarianism and Vote Choice in the 2012 Elections}

\section{Authoritarians vs. Non-authoritarians}

I begin with the impact of authoritarianism on the vote for incumbents without including race distinctions. Since the dependent variables are dichotomous, I used logistic regression to estimate two models for each of the 
dependent variables. The first model measures the effect of authoritarianism when the incumbent running for re-election is a Republican (Authoritarianism (R)) and the second measures the effect of authoritarianism when the incumbent is a Democrat (Authoritarianism (D)).

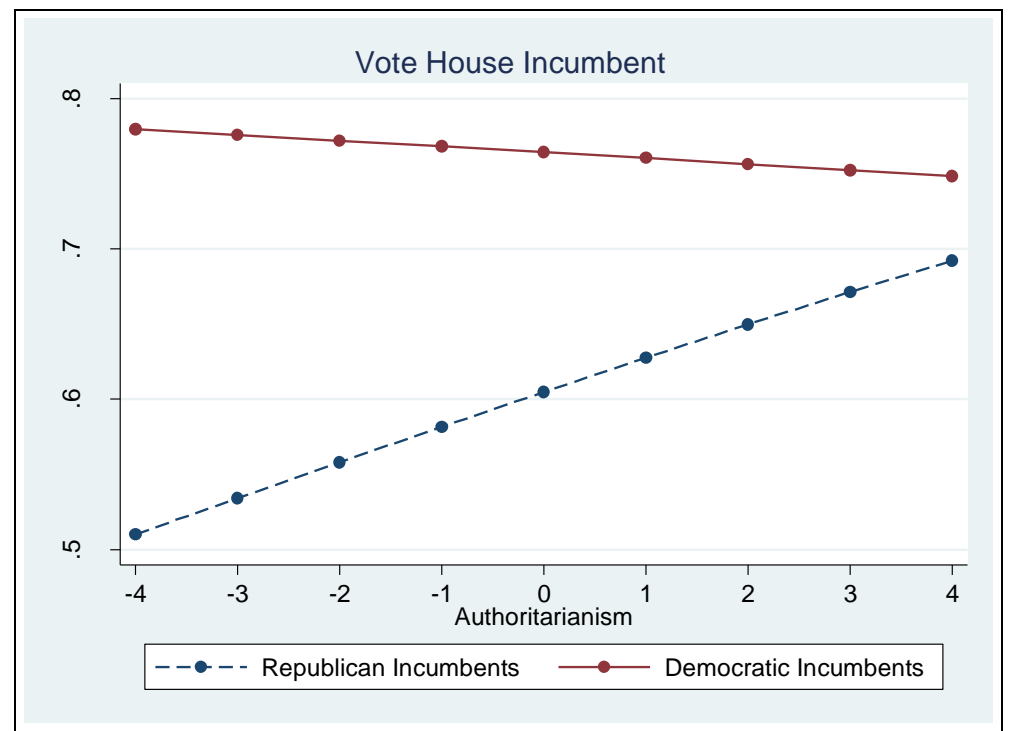

Figure 1. Vote house incumbent.

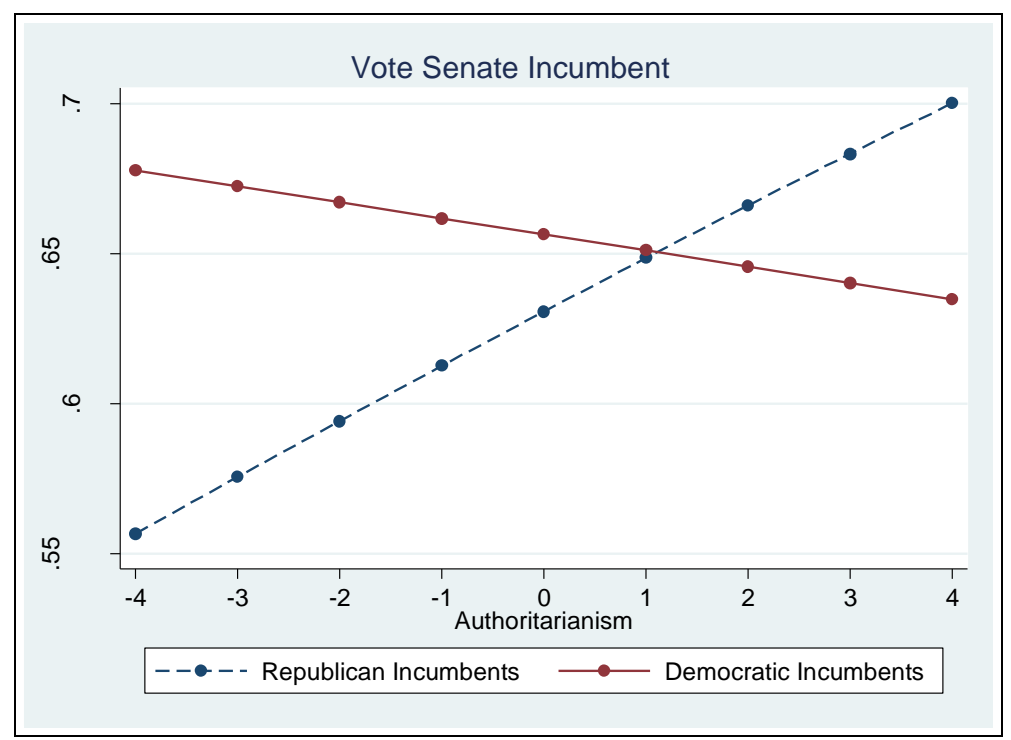

Figure 2. Vote senate incumbent.

The results in Table 1 demonstrate that authoritarianism plays significant role in support for incumbents when the incumbent is a Republican. There is a positive and significant relationship between authoritarianism and support for Republican incumbents in both the House and the Senate. According to these estimates, the most authoritarian voter has a 0.70 probability of voting for Republican incumbents in the Senate and a 0.69 probability of voting for Republican incumbents in the House. The least authoritarian voter has a 0.56 probability of voting for Republican incumbents in the Senate and a near 0.50 probability of voting for Republican incumbents in the House. Conversely, the results indicate that there is not a statistically significant 
relationship between authoritarianism and vote choice when the incumbent is a Democrat. Figures 1 and 2 also show that, as authoritarianism increases, the likelihood to vote for a Republican incumbent increases much more rapidly than the likelihood to vote for a Democratic incumbent decreases, an effect that is perhaps supportive of the assertion that incumbents remain preferable to challengers amongst authoritarians. ${ }^{2}$

The results from my analysis of authoritarians as a whole lend partial credibility to my first hypothesis, but it is clear that support for incumbents depends heavily on the PID of the incumbent. It is also important to note that, since I control for PID, the partisan effect that we see in support for incumbents is not entirely explained by the respondents' PID. Next, in order to test my second hypothesis, I take a look at the effect of authoritarianism on the vote choice of Black and White respondents separately.

\section{White Authoritarians vs. Black Authoritarians}

To assess the degree to which White authoritarians viewed Obama as threat in spite of his incumbency status, I first test the effect of authoritarianism on the vote choice for Senate and House incumbents amongst White respondents. The logit results in Table 2 show patterns similar to those in Table 1. For White respondents, the effect of authoritarianism on the vote for Republican incumbents is both positive and significant. The most authoritarian respondent amongst Whites has a near 0.90 probability of voting for a Republican incumbent in the Senate and a little over 0.80 probability of supporting Republican incumbents in the House.

Table 2

The Effect of Authoritarianism on Senate, House and Presidential Incumbents, 2012 (Whites Only) (Standard Errors in Parentheses)

\begin{tabular}{lcll}
\hline Dependent Variables & & & \\
\hline Authoritarianism & $\begin{array}{l}\text { Senate Incumbent Vote } \\
(N=1,366)\end{array}$ & $\begin{array}{l}\text { House Incumbent Vote } \\
(N=1,807)\end{array}$ & $\begin{array}{l}\text { Vote Obama } \\
(N=2,416)\end{array}$ \\
\hline Authoritarian (R) & $0.45^{* * *}$ & $0.24 * * *$ & $-0.16^{* * * 3}$ \\
& $(0.076)$ & $(0.030)$ & $(0.030)$ \\
Authoritarian (D) & $-0.09 * * *$ & 0.02 & - \\
& $(0.033)$ & $(0.030)$ & -0.01 \\
Income & 0.0004 & -0.003 & $(0.009)$ \\
Female & $(0.009)$ & $(0.007)$ & -0.02 \\
& 0.21 & 0.03 & $(0.138)$ \\
Age & $(0.137)$ & $(0.104)$ & -0.01 \\
& -0.005 & -0.001 & $(0.004)$ \\
Education & $(0.004)$ & $(0.003)$ & 0.16 \\
& 0.13 & -0.007 & $(0.071)$ \\
PID & $(0.071)$ & $(0.053)$ & $-1.26^{* * *}$ \\
& $-0.66 * * *$ & $-0.05 *$ & $(0.400)$ \\
\hline
\end{tabular}

Source: 2012 American National Election Studies.

Notes. $* p<0.10 ; * * p<0.05 ; * * * p<0.01$.

${ }^{2}$ Interestingly, in spite of the fact that support for Republican incumbents increases as authoritarianism increases, the probability of voting for a Democratic incumbent in the House is still higher than the probability of voting for a Republican incumbent in 2012.

${ }^{3}$ Indicates the effect of authoritarianism on the vote for Obama; No PID distinctions are made. Estimates do not include sample weights. 
The least authoritarian respondent amongst Whites has a near 0.40 probability of voting for Democratic incumbents in both the House and the Senate. In addition, although the effect is insignificant in the House election, the relationship between authoritarianism and the vote for Democratic incumbents is negative and significant in the Senate election. In other words, White respondents are significantly more likely to vote for Republican Senate incumbents and significantly less likely to support Democratic Senate incumbents. Finally, as expected, in the 2012 presidential election, authoritarianism exerts a negative influence on the likelihood to vote for Obama amongst White respondents.

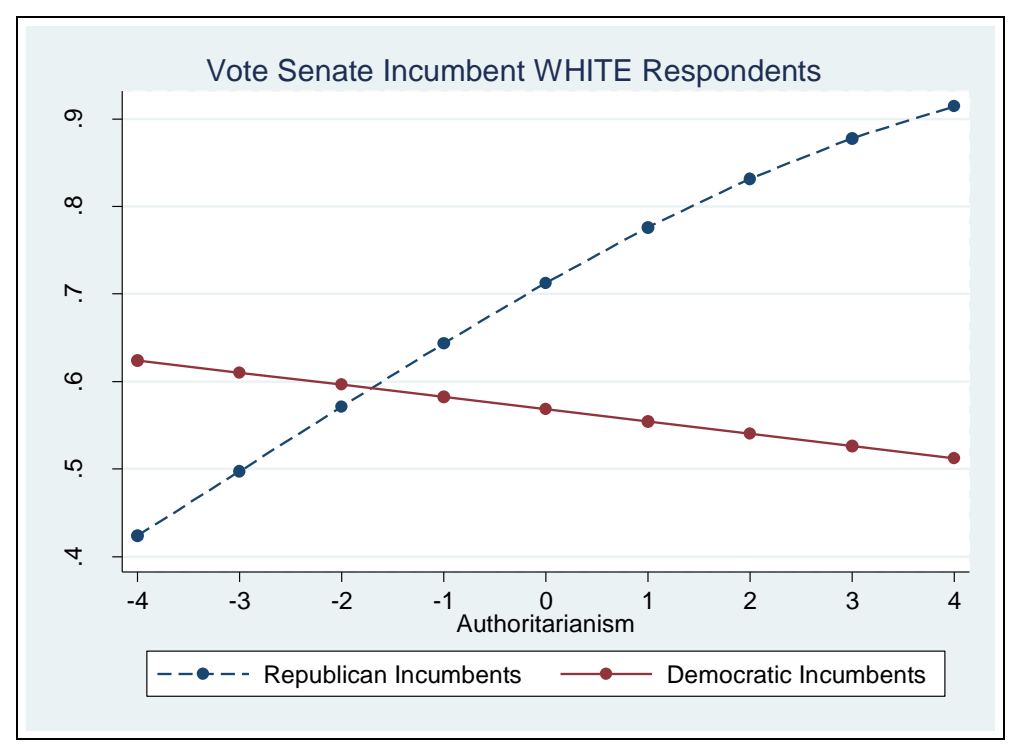

Figure 3. Vote senate incumbent WHI TE respondents.

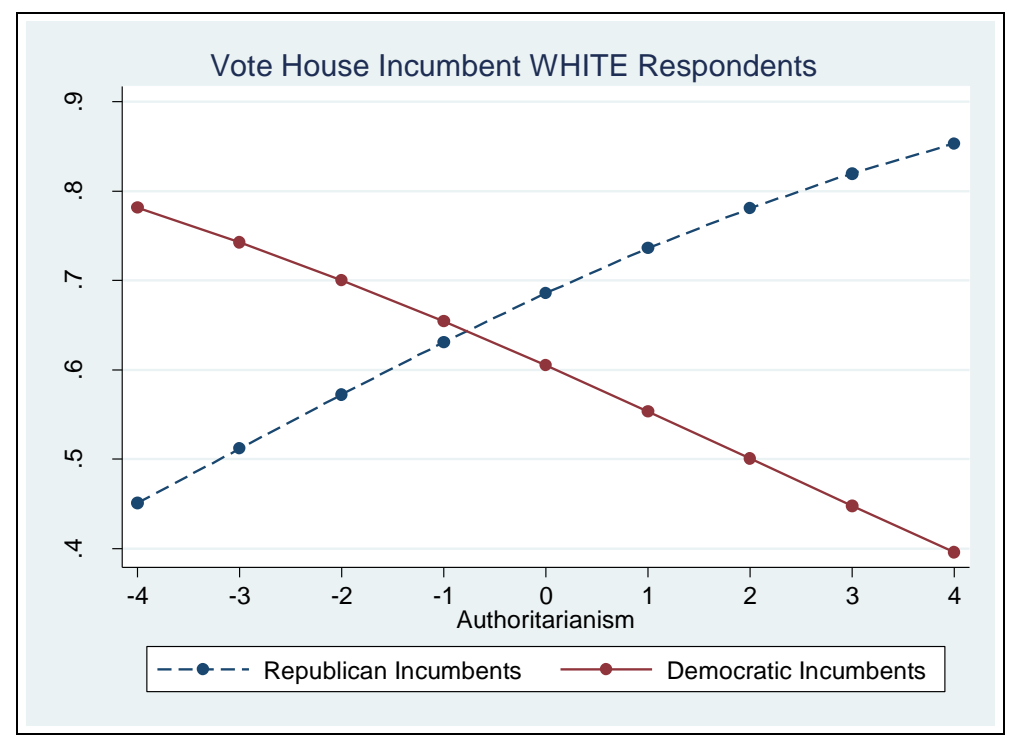

Figure 4. Vote house incumbent WHI TE respondents.

For Black respondents, authoritarianism did not have an effect on the vote for incumbents in the House or Senate regardless of the incumbents' PID (see Table 3). Unlike White authoritarians, it seems as though the most authoritarian, Black respondent is highly unlikely to vote for Republican incumbents (Figures 5 and 6), 
but not much can be said because the effect of authoritarianism is insignificant. More surprisingly, the results show that authoritarianism did not significantly predict the vote choice of Black respondents in the presidential election. Prima facie, the results from Tables 2 and 3 support my second hypothesis, but further discussion is needed to flesh out the nuances.

Table 3

The Effect of Authoritarianism on Senate, House and Presidential Incumbents, 2012 (Blacks Only) (Standard Errors in Parentheses)

\begin{tabular}{llll}
\hline Dependent Variables & & & \\
\hline Authoritarianism & $\begin{array}{l}\text { Senate Incumbent Vote } \\
(N=308)\end{array}$ & $\begin{array}{l}\text { House Incumbent Vote } \\
(N=523)\end{array}$ & $\begin{array}{l}\text { Vote Obama } \\
(N=2416)\end{array}$ \\
\hline Authoritarian (R) & 0.14 & -0.03 & $-0.06^{4}$ \\
& $(0.328)$ & $(0.101)$ & $(0.139)$ \\
Authoritarian (D) & 0.04 & -0.03 & - \\
& $(0.148)$ & $(0.068)$ & - \\
Income & -0.07 & 0.04 & 0.01 \\
& $(0.050)$ & $(0.029)$ & $(0.042)$ \\
Female & 0.20 & 0.12 & 0.79 \\
& $(0.643)$ & $(0.397)$ & $(0.655)$ \\
Age & 0.015 & -0.02 & -0.02 \\
& $(0.021)$ & $(0.013)$ & $(0.021)$ \\
Education & 0.24 & -0.39 & -0.15 \\
& $(0.327)$ & $(0.199)$ & $(0.314)$ \\
PID & $-0.68^{* * *}$ & 0.18 & $-0.97 * *$ \\
& $(0.181)$ & $(0.161)$ & $(0.147)$ \\
\hline
\end{tabular}

Source: 2012 American National Election Studies

Notes. ${ }^{*} p<0.10,{ }^{* *} p<0.05,{ }^{* * *} p<0.01$.

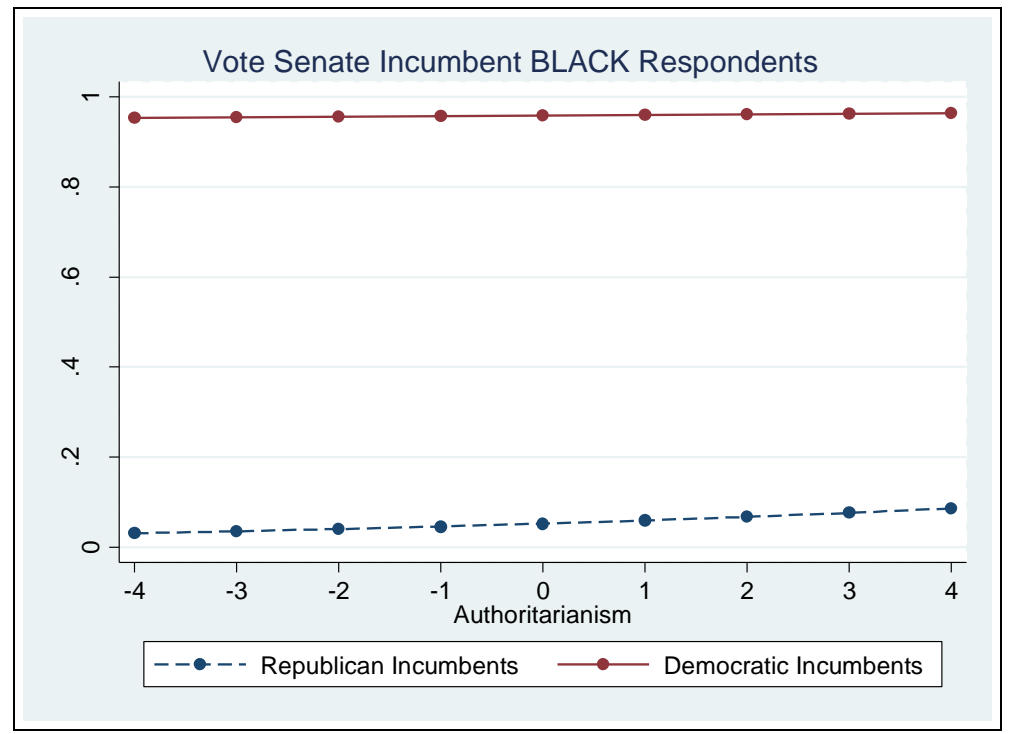

Figure 5. Vote senate incumbent black respondents.

\footnotetext{
${ }^{4}$ Indicates the effect of authoritarianism on the vote for Obama; no PID distinctions are made. Estimates do not include sample weights.
} 


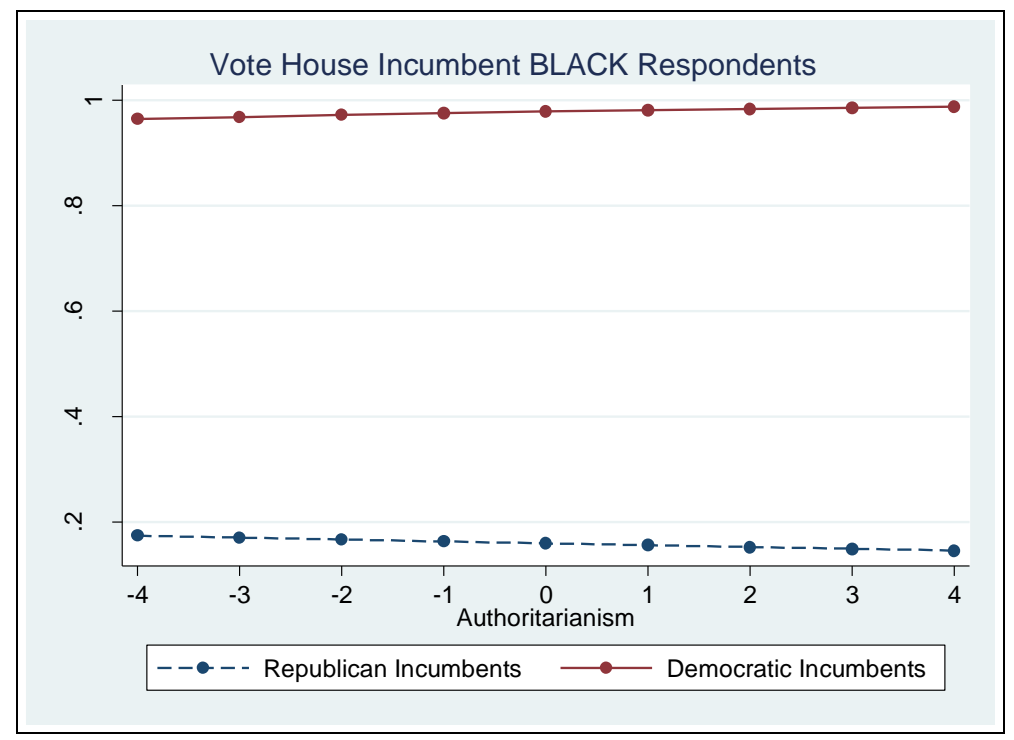

Figure 6. Vote house incumbent black respondents.

\section{Discussion}

The literature clearly distinguishes authoritarianism from conservatism, but my results imply that they manifest themselves in similar ways: as support for the Republican Party. As evidenced by Figures 1 and 2, non-authoritarians also have a high probability of voting for Congressional incumbents, but, unlike authoritarians, they are more likely to vote for Democratic incumbents. In theory, either Republicans or Democrats can use levels of perceived threat to their advantage depending on the nature of the threat. Conservative leaders seem like the natural choice for authoritarians because of the value that they place on social norms. However, liberals can also utilize threat to garner electoral support when conservatives propose solutions that seem ambiguous or unorganized (Hetherington \& Weiler, 2009). In 2012, it seems as though the perception of Obama as a social and political threat resulted in authoritarian support for the Republican Party. However, the fact that authoritarians are more likely to vote for Republican incumbents as opposed to Democratic ones also suggests that Obama's Democratic affiliation could have hurt his chances amongst White authoritarians. Therefore, the initial conundrum of whether a candidate's reputation as an established authority or the perception of threat surrounding an election remains, although the findings of Sniderman and Piazza (1993) and Huddy et al. (2005) in conjunction with my findings indicate that it was the latter in 2012. Although, theoretically, the most competent leader and not the leader's party should persuade authoritarians, my results support previous findings of the growing relationship between authoritarianism and Republican affiliation.

That authoritarianism factors into the vote choice of Whites constituents but not Blacks warrants further inquiry. There are a few explanations for the results that we see here. Sampling weights were not used in any of the estimates in order to utilize the Black oversample in the dataset. However, it is possible that there was simply not enough variation amongst Black respondents to indicate an effect for the Senate and House Incumbent Vote estimates. Another possible explanation is that Black authoritarians are not as invested in protecting social and political status quos because the norms used to support them exclude minority participation and perspectives. If that were the case, authoritarianism would not weigh heavily into the political decision-making processes of Black authoritarians in spite of the fact that they share the same parenting 
orientations as their White counterparts (Masuoka \& Junn, 2013). However, such an argument undermines the very essence of what it means to be characterized as an authoritarian. While it is true that not all authoritarians perceive the same circumstances as threatening, what holds authoritarians together is their experience of threats as challenges to existing social norms. To suggest that Black authoritarians do not value traditional constructs as highly as White authoritarians is to question their qualification as authoritarian altogether.

A third and much stronger explanation for the discrepancies that we see between the impact of authoritarianism on the vote choice of Black versus White Americans is that there are other factors take precedence over authoritarianism when it comes to Black constituents' voting behavior, namely PID. That is not to say that Black authoritarians are any less "authoritarian" than Whites. Remember, authoritarianism is a worldview that is not easily shed at one's convenience. However, I would argue that, while authoritarianism may have an impact on the behavior of Black authoritarians in social circumstances, it might not impact their political decision-making because, for the majority of Black constituents (regardless of their individual preferences), voting for Democratic candidates is an automatic heuristic. The Democratic Party has been the champion of minority rights for decades and, although PID was significant for both Whites and Blacks in the regressions, it is possible that Democratic affiliation simply trumps the effect of authoritarianism when it comes to political support amongst Blacks. It is plausible that, in spite of their shared parenting orientations, Black authoritarians experience the impact of authoritarianism in social circumstances rather than political ones while White authoritarians are effected by it in both.

Although not much has been said about challengers until this point, Figures 1 and 2 show that, for authoritarians in general, the likelihood of voting for democratic incumbents as opposed to democratic challengers is slightly higher in the Senate elections and substantially higher in the House elections ${ }^{5}$. This observation does not hold once race distinctions are made but it generally reinforces the idea that, as a whole, authoritarians exhibit their risk-averse tendencies in the form of incumbent support. In spite of the fact that authoritarianism is overwhelmingly linked with support for Republican incumbents, Democratic incumbents still receive an advantage over Democratic challengers. Regardless of whether it can be traced back to a risk-adverse orientation or not, it appears that authoritarians have a political preference for incumbents over challengers.

\section{Conclusion}

At the beginning of this paper, I asked whether authoritarians are more likely to vote for incumbents as opposed to challengers. I attempted to answer that question by testing whether White authoritarians deviated from a baseline tendency to vote for incumbents whereas Black authoritarians adhered to it in the 2012 presidential election. I find evidence that authoritarians have risk-averse orientations that manifest themselves as support for Congressional incumbents, but this finding is heavily dependent on two factors: the race of the respondent and the PID of the incumbent. In spite of the distinctions that scholars make between authoritarianism and similar dispositions that are linked to polarization, in the case of White respondents, authoritarianism is positively and significantly linked with support for the Republican Party. Conversely, according to these estimates, authoritarianism does not predict the vote choice of Black authoritarians at all.

\footnotetext{
5 There is an approximately 0.37 probability of voting for Democratic challengers as opposed to a 0.63 probability for Democratic incumbents in the Senate election and a 0.23 probability of voting for Democratic challengers as opposed to a 0.77 probability for Democratic incumbents in the House election.
} 
Even if authoritarians as a whole rely on established authorities and value the same social norms, their voting behavior appears to be substantially different when it comes to supporting incumbents depending on race.

My work speaks to the literature on authoritarianism in two ways. First, when making characterizations about authoritarian propensities, it is important to note that they do not all hold the same weight. For authoritarians, relying on established authorities is a tendency that allows them to minimize ambiguity and confusion. However, in certain circumstances, perceived threat seems to override the propensity to rely on familiar candidates for White authoritarians. Second, the results regarding Black respondents imply that authoritarianism works differently depending on race. The need for social order and conformity is a racially exclusive characteristic. However, the effect of authoritarianism is often racial bias, suggesting that authoritarianism is, in some ways, influenced by the acceptance or opposition of social norms that are laden with racial categorizations. The links between authoritarianism and Republican affiliation may, therefore, be a result of elite cues that focus on framing social and racial minorities as a threat as opposed to the actual provision of order or clarity on the part of the Republican Party. This paper makes the case for further research about how authoritarianism works in minority Americans. In light of the fact that racial minorities tend to score high on authoritarianism, it is important to include analyses of its effects for these groups independent of Whites.

Overall, my findings have important implications for Democratic and Republican incumbents and challengers. While Republican incumbents enjoy the majority of White authoritarians' support, the centrality of threat perception in the authoritarian worldview implies that the circumstances surrounding an election can substantially influence their vote behavior. Republican incumbents may not have to work substantially hard to receive authoritarian support, but there is no evidence that authoritarians are a reliable constituent-base. For Republican challengers, gaining authoritarian support will most likely rely on their ability to sell themselves as competent leaders. Although they are fighting an uphill battle in comparison to Republican incumbents, when it comes to Senate elections in particular, Republican challengers may have a better chance of leveraging support from White authoritarians in comparison to their Democratic counterparts. Conversely, the implications for Democratic candidates are not as dire. For Democratic incumbents in particular, it seems as though authoritarianism simply does not factor into their chances for reelection.

As measured by support for incumbent candidates, the results suggest that authoritarians do, on average, exhibit risk-averse voting behavior, but further research on the effect on authoritarianism on the vote for challengers could help support or undermine this conclusion. Extending my research to previous elections would also allow for a better interpretation of my findings in 2012. As a particularly responsive subset of the American population, scholars will benefit from a more comprehensive knowledge about the voting behavior of authoritarians as a whole and the electoral impact of their innate tendencies in particular.

\section{References}

Alvarez, R. M. (1997). Information and elections. Ann Arbor: University of Michigan Press.

Bartels, L. M. (1986). Issue voting under uncertainty: An empirical test. American Journal of Political Science, 30(4), 709-728.

Feldman, S. (2003). Values, ideology, and the structure of political attitudes. In D. O. Sears, L. Huddy, \& R. Jervis (Eds.), Oxford Handbook of Political Psychology (pp. 477-508). New York: Oxford University Press.

Hetherington, M. J., \& Weiler, J. D. (2009). Authoritarianism and polarization in American politics. New York: Cambridge University Press. 
Huddy, L., Feldman, S., Taber, C., \& Lahav, G. (2005). Threat, anxiety, and support of anti-terrorism policies. American Journal of Political Science, 49, 610-625.

Kam, C. D., \& Kinder, D. R. (2012). Ethnocentrism as a short-term force in the 2008 American Presidential Election. American Journal of Political Science, 56(2), 326-340.

Kam, C. D., \& Simas, E. N. (2010). Risk orientation and policy frames. The Journal of Politics, 72(2), 381-396.

Kam, C. D., \& Simas, E. N. (2012). Risk attitudes, candidate characteristics, and vote choice. Public Opinion Quarterly, 76(4), 747-760.

Masuoka, N., \& Junn, J. (2013). The politics of belonging: Race, public opinion, and immigration. University of Chicago Press. Introduction and Chapter 1: Public Opinion through a Racial Prism.

Sniderman, P., \& Piazza, T. (1993). The scar of race. Cambridge, MA: Harvard University Press.

Stenner, K. (2005). The authoritarian dynamic. Cambridge: Cambridge University Press. 